\title{
KALIBRASI SPEKTROFOTOMETER SEBAGAI PENJAMINAN MUTU HASIL PENGUKURAN DALAM KEGIATAN PENELITIAN DAN PENGUJIAN
}

\author{
Anom Irawan \\ ${ }^{1}$ Laboratorium Pengujian dan Penelitian Terpadu, Universitas Gadjah Mada, Yogyakarta. \\ 55281.e-mail: anom@ugm.ac.id
}

Submisi : 27 Oktober 2018; Penerimaan: 19 Februari 2019

\begin{abstract}
ABSTRAK
Kalibrasi menentukan perbedaan (deviasi) antara pembacaan alat ukur dengan bahan ukur (sebagai standar) dengan (taksiran) nilai benar. Tujuan kalibrasi spektrofotometer adalah untuk mengetahui nilai perbedaan dari pembacaan alat dengan membandingkan nilai standar, sehingga dapat menjamin data yang benar dan valid.

Bahan standar/kalibrator untuk mengkalibrasi Spektrofotometer meliputi, akurasi panjang gelombang dengan Holmium oxide (liquid atau solid) dan Dydimium solid. Sedang untuk akurasi fotometri dengan bahan acuan $\mathrm{K}_{2} \mathrm{Cr}_{2} \mathrm{O}_{7}$ 0,006\% dalam larutan $\mathrm{HClO}_{4} 0,001 \mathrm{~N}$ (range lamda $235 \mathrm{~nm}-350 \mathrm{~nm}$ ) dan $\mathrm{K}_{2} \mathrm{Cr}_{2} \mathrm{O}_{7}$ 0,06\% dalam larutan $\mathrm{HClO}_{4}$ $0,001 \mathrm{~N}$ (lamda $430 \mathrm{~nm}$ ). Straylight dengan larutan $\mathrm{KCl}$ 1,2\%. Daya pisah/ Resulotion menggunakan larutan Toluen dalam Heksan 0,02\%. Linieritas Detektor menggunakan larutan komlpeks standar Phospat untuk dibuat kurva baku.

Hasil kegiatan kalibrasi Spektrophotometer Shimadzu UV 1800 yaitu Akurasi panjang gelombang dengan Holmium oxide pada lamda yang ditentukan tidak terjadi pergeseran puncak dengan toleransi $\pm 1 \mathrm{~nm}$ rentang UV dan $\pm 3 \mathrm{~nm}$ visible (Pharmacopeia Eropa). Akurasi Fotometri dengan larutan K2Cr2O7 0,006\% dalam HClO4 0,001 N nilai absorbansi masih dalam range. Toleransi absorbansi adalah $\pm 0,01$ dari pembacaan alat terhadap nilai sertifikat standar. Pengukuran Straylight dengan Larutan $\mathrm{KCl}$ 1,2\% pada lamda $198 \mathrm{~nm}$ memberikan nilai absorbansi >2. Pengukuran Resolution dengan larutan Tolluen dalam Hexan antara panjang gelombang 268,7 nm dengan 267,0 $\mathrm{nm}$ memberikan nilai absorbansi yang berbeda. Nilai perbedaan >- 1,5 (Pharmacopeia Eropa). Kalibrasi Spektrofotometer Shimadzu UV 1800 di LPPT UGM, nilai pengukuran yang di dapat dan di bandingkan dengan nilai standar masih masuk dalam toleransi, sehingga alat masih valid digunakan dalam kegiatan penelitian dan pengujian sampel di LPPT UGM.
\end{abstract}

Kata kunci : Kalibrasi; Spektrofotometer; Standar; Kalibrator.

\section{PENDAHULUAN}

Kalibrasi adalah serangkaian kegiatan untuk menetapkan hubungan, dalam kondisi tertentu antara suatu nilai besaran yang ditunjukan oleh peralatan ukur atau sistem pengukuran, atau nilai yang dipresentasikan oleh bahan ukur atau bahan acuan dengan nilai terkait yang direalisasikan oleh standar (Vocabulary of Basic and General Teams in Metrology-VIM 1993). Kalibrasi menentukan perbedaan (deviasi) antara pembacaan alat ukur atau bahan ukur (yang digunakan sebagai standar) dengan (taksiran) nilai benar. Hasil kalibrasi dapat berupa penetapan koreksi yang berkaitan dengan penunjukan alat ukur. Kalibrasi dapat juga menetapkan sifat metrologis lainnya, termasuk efek besaran berpengaruh. Hasil kalibrasi direkam dalam dokumen yang biasa disebut sertifikat kalibrasi. Deviasi atau penyimpangan dapat dinyatakan sebagai koreksi atau kesalahan (error) dengan model matematis : $E=R-T$ atau $C=T-R$ di mana $E$ : Kesalahan, 


\section{A. Irawan/Vol 1 (2) 2019, 1-9}

C : Koreksi, R : Pembacaan alat ukur dan $\mathrm{T}$ : (Taksiran) nilai benar. Spektrofotometer

UV-VIS

adalah salah satu metode instrumen yang paling sering diterapkan dalam analisis kimia untuk mendeteksi senyawa (padat/cair) berdasarkan absorbansi foton. Agar sampel dapat menyerap foton pada daerah UV-VIS (panjang gelombang foton $200 \mathrm{~nm}-700$ $\mathrm{nm})$, biasanya sampel harus diperlakukan atau derivatisasi, misalnya penambahan reagen dalam pembentukan garam kompleks dan lain sebagainya. Unsur diidentifikasi melalui senyawa kompleksnya. Persyaratan kualitas dan validitas kinerja hasil pengukuran spektrofotometer dalam analisis kimia didasarkan pada acuan ISO 17025, Good Laboratory Practice (GLP) atau rekomendasi dari Pharmacopeia (EP, DAB, USP).

Dalam ISO 17025 (2005) butir 5.5 di nyatakan bahwa alat uji yang menentukan hasil pengukuran harus dikalibrasi. Spektrofotometer UV-VIS merupakan alat utama maka harus di kalibrasi. Kalibrasi instrumen Spektrofotometer meliputi: Akurasi Panjang Gelombang , Akurasi fotometri, Resolution, Kebocoran sinar/Straylight, Base line Stability, base line flatnest, dan akurasi detektor.

\section{TUJUAN}

Pengukuran kalibrasi Spektrofotometer UV-VIS (Shimadzu UV 1800) di LPPT UGM ini bertujuan untuk mengetahui unjuk kinerja instrumen apakah masih sesuai dengan standar yang dipersyaratkan apa tidak. Dengan mengetahui unjuk kinerja alat maka akan dapat menjamin mutu hasil data pengukuran dalam kegiatan penelitian maupun pengujian

\section{LATAR BELAKANG}

\begin{abstract}
Latar belakang dilakukan kalibrasi spektrofotometer adalah melaksanakan ketentuan ISO 17025 (2005) butir 5.5 yang menyatakan bahwa alat uji yang menentukan hasil pengukuran harus/wajib dikalibrasi. Mengingat jumlah pemakaian instrument yang banyak dan sering, maka perlu di lakukan pengecekan unjuk kinerja alat dengan kalibrasi.
\end{abstract}

\section{METODE PENELITIAN Bahan}

Bahan yang digunakan antara lain: Standar Kalibrator Holmium oxide glass/liquid filter, Didymium glass filter, larutan $\mathrm{K}_{2} \mathrm{Cr}_{2} \mathrm{O}_{7}$ dalam $\mathrm{HClO}_{4} 0,001 \mathrm{~N}$ (konsentrasi $0,006 \%$ dan $0,06 \%$ ), larutan $\mathrm{Nal} 10 \%$ atau $\mathrm{KCl} 1,2 \%$, larutan Toluen dalam Heksan 0,02\%, larutan komlpeks standar Phospat dengan Amonium Molibdovanadat, Aquades dan kertas tissue.

Alat

Alat yang digunakan adalah Instrumen Spektrofoptometer UV-VIV (Shimadzu UV-1800).

\section{Cara kerja}

1. Dinyalakan Instrumen Spektofotometer uv-vis sesuai sengan SOP, tunggu selama 1 jam.

2. Pengukuran baseline flatness dari range panjang gelombang terendah sampai yang tertinggi.

3. Pengukuran baseline stability dengan memilih panjang gelombang tertentu, misalnya 700 nm selama 1 jam.

4. Pengukuran Akurasi Panjang gelombang dengan menggunakan Filter Holmium oxide, pilih menu spectrum pada instrumen, set scan panjang gelombang $260 \mathrm{~nm}$ sampai dengan $650 \mathrm{~nm}$. Jika memakai filter Holmium Oxide cair, set scan 


\section{A. Irawan/Vol 1 (2) 2019, 1-9}

panjang gelombang $240 \mathrm{~nm}$ sampai $645 \mathrm{~nm}$. Perulangan $10 \mathrm{x}$ scan

5. Pengukuran akurasi panjang gelombang dengan menggunakan filter Didymium, set scan panjang gelombang $320 \mathrm{~nm}$ sampai dengan $880 \mathrm{~nm}$. Perulangan $10 \mathrm{x}$ scan.

6. Pengukuran akurasi fotometri dengan larutan Kalium dikromat $0,006 \%$ dalam larutan $\mathrm{HClO}_{4}$ $0,001 \mathrm{~N}$, pilih menu Photometri pada instrumen, set panjang gelombang $235 \mathrm{~nm}, 257 \mathrm{~nm}, 313$ $\mathrm{nm}, 350 \mathrm{~nm}$ dengan blangko pelarut. Pembacaan $10 \mathrm{x}$ perulangan.

7. Pengukuran akurasi fotometri dengan larutan Kalium dikromat $0,06 \%$ dalam larutan $\mathrm{HClO}_{4}$ $0,001 \mathrm{~N}$, pilih menu Photometri pada instrumen, set panjang gelombang $430 \mathrm{~nm}$ dengan blangko pelarut. Pembacaan $10 \mathrm{x}$ perulangan.

8. Pengukuran sinar sesatan/straylight dengan menggunakan larutan $\mathrm{Nal}$ $10 \%$, pilih menu Photometri pada instrumen, set panjang gelombang $220 \mathrm{~nm}$ dengan blangko pelarut. Pembacaan $10 \times$ perulangan. Menggunakan larutan $\mathrm{KCl} 1,2 \%$, pilih menu Photometri pada instrumen, set panjang gelombang 198 nm dengan blangko pelarut. Pembacaan 10 x perulangan.
9. Pengukuran daya pisah/resulotion dengan menggunakan larutan Toluen dalam Heksan 0,02\%, pilih menu Photometri pada instrumen, set panjang gelombang $268,7 \mathrm{~nm}$ dan 267,0 nm dengan blangko pelarut. Pembacaan $10 \mathrm{x}$ perulangan.

10. Pengukuran Linieritas Detektor dengan menggunakan larutan seri standar Phospat konsentrasi 0 ppm sampai dengan $32 \mathrm{ppm}$. Plih menu Photometri pada instrumen, set panjang gelombang $430 \mathrm{~nm}$ dengan blangko pelarut. Pembacaan 10 x perulangan.

\section{HASIL DAN PEMBAHASAN}

\section{A. HASIL}

Setelah instrumen dinyalakan selama 1 jam dilakukan pengukuran baseline flatness dari lamda terendah sampai tertinggi, hasil pembacaan scan alat nilai absorbansi 0,0002. Nilai absorbansi toleransi pada instrumen $\pm 0,0010$ Abs. Pada pengukuran baseline stability lamda $700 \mathrm{~nm}$ selama 1 jam, diperoleh nilai absorbansi 0,0003 Abs/H, sedang toleransi nilai absorbansi pada alat adalah 0,0010 Abs/H atau kurang. Pada Pengkuran Akurasi Panjang Gelombang dengan menggunakan filter Holmium Oxide glass di ambil 5 titik panjang gelombang di dapat hasil :

Tabel 1. Data pengukuran panjang gelombang dengan Holmium Oxide glass

\begin{tabular}{|c|c|c|c|c|c|c|c|c|c|c|c|c|}
\hline \multirow{2}{*}{ No } & \multirow{2}{*}{$\begin{array}{c}\text { Panjang } \\
\text { Gelombang } \\
\text { dari SRM } \\
2034\end{array}$} & \multicolumn{10}{|c|}{ Hasil pengukuran panjang gelombang $(\mathrm{nm})$} & \multirow{2}{*}{$\begin{array}{l}\text { Standar } \\
\text { Deviasi }\end{array}$} \\
\hline & & 1 & 2 & 3 & 4 & 5 & 6 & 7 & 8 & 9 & 10 & \\
\hline 1 & 279,30 & 279,5 & 279,5 & 279,5 & 279,5 & 279,5 & 279,5 & 279,5 & 279,5 & 279,5 & 279,5 & 0,00 \\
\hline 2 & 360,85 & 361,0 & 361,0 & 361,0 & 361,0 & 361,0 & 361,0 & 361,0 & 361,0 & 361,0 & 361,0 & 0,00 \\
\hline 3 & 453,60 & 453,5 & 453,5 & 453,5 & 453,5 & 453,5 & 453,5 & 453,5 & 453,5 & 453,5 & 453,5 & 0,00 \\
\hline 4 & 536,40 & 536,5 & 536,5 & 536,5 & 536,5 & 536,5 & 536,5 & 536,5 & 536,5 & 536,5 & 536,5 & 0,00 \\
\hline 5 & 637,65 & 637,5 & 637,5 & 637,5 & 637,5 & 637,5 & 637,5 & 637,5 & 637,5 & 637,5 & 637,5 & 0,00 \\
\hline
\end{tabular}


Tabel 2. Hasil pengukuran panjang gelombang dengan Holmium Oxide glass

\begin{tabular}{|c|c|c|c|c|c|}
\hline No & $\begin{array}{c}\text { Panjang } \\
\text { Gelombang } \\
\text { dari SRM } \\
\mathbf{2 0 3 4}\end{array}$ & $\begin{array}{c}\text { Ketidakpastian } \\
\text { Standar ( } \mathbf{(} \mathbf{n m}\end{array}$ & $\begin{array}{c}\text { Rata-rata } \\
\text { pembacaan } \\
\text { panjang } \\
\text { gelombang(nm) }\end{array}$ & Koreksi & $\begin{array}{c}\text { Ketidakpastian } \\
\mathbf{( \pm )} \mathbf{n m}\end{array}$ \\
\hline $\mathbf{1}$ & 279,30 & 0,2 & 279,5 & 0,20 & 0,61 \\
\hline $\mathbf{2}$ & 360,85 & 0,2 & 361,0 & 0,15 & 0,61 \\
\hline $\mathbf{3}$ & 453,60 & 0,2 & 453,5 & $-0,10$ & 0,61 \\
\hline $\mathbf{4}$ & 536,40 & 0,2 & 536,5 & 0,10 & 0,61 \\
\hline $\mathbf{5}$ & 637,65 & 0,2 & 637,5 & $-0,15$ & 0,61 \\
\hline
\end{tabular}

Nilai Koreksi pada lamda 5 titik tabel di atas, semua koreksi masih masuk dalam toleransi $\pm 1 \mathrm{~nm}$ untuk area UV dan $2 \mathrm{~nm}$ utk area Visibel. Maka instrumen masih akurasi dalam penunjukan lamdanya dan nilai pergeserannya tidak bermakna.

Tabel 3. Data pengukuran Akurasi panjang gelombang dengan filter Holmium Oxide cair :

\begin{tabular}{|c|c|c|c|c|c|c|c|c|c|c|c|c|}
\hline \multirow{2}{*}{ No } & \multirow{2}{*}{$\begin{array}{l}\text { Panjang } \\
\text { Gelombang } \\
\text { dari SRM } \\
2034\end{array}$} & \multicolumn{10}{|c|}{ Hasil pengukuran panjang gelombang $(\mathrm{nm})$} & \multirow{2}{*}{$\begin{array}{l}\text { Standar } \\
\text { Deviasi }\end{array}$} \\
\hline & & 1 & 2 & 3 & 4 & 5 & 6 & 7 & 8 & 9 & 10 & \\
\hline 1 & 241,20 & 241,0 & 241,0 & 241,0 & 241,0 & 241,0 & 241,0 & 241,0 & 241,0 & 241,0 & 241,0 & 0,00 \\
\hline 2 & 287,25 & 287,0 & 287,5 & 287,5 & 287,5 & 287,5 & 287,5 & 287,5 & 287,5 & 287,0 & 287,5 & 0,21 \\
\hline 3 & 361,35 & 361,5 & 361,5 & 361,0 & 361,5 & 361,5 & 361,0 & 361,5 & 361,5 & 361,5 & 361,5 & 0,21 \\
\hline 4 & 536,65 & 536,5 & 536,5 & 536,5 & 536,5 & 536,5 & 536,5 & 536,5 & 536,5 & 536,5 & 536,5 & 0,00 \\
\hline 5 & 640,55 & 640,5 & 640,5 & 640,5 & 640,5 & 640,5 & 640,5 & 640,5 & 640,5 & 640,5 & 640,5 & 0,00 \\
\hline
\end{tabular}

Tabel 4. Hasil pengukuran Akurasi panjang gelombang dengan filter Holmium Oxide cair

\begin{tabular}{|c|c|c|c|c|c|}
\hline No & $\begin{array}{c}\text { Panjang } \\
\text { Gelombang } \\
\text { dari SRM } \\
\mathbf{2 0 3 4}\end{array}$ & $\begin{array}{c}\text { Ketidakpastian } \\
\text { Standar ( } \mathbf{(} \mathbf{n m}\end{array}$ & $\begin{array}{c}\text { Rata-rata } \\
\text { pembacaan } \\
\text { panjang } \\
\text { gelombang(nm) }\end{array}$ & Koreksi & $\begin{array}{c}\text { Ketidakpastian } \\
\mathbf{( \pm )} \mathbf{~ n m}\end{array}$ \\
\hline $\mathbf{1}$ & 241,20 & 0,2 & 241,0 & $-0,20$ & 0,61 \\
\hline $\mathbf{2}$ & 287,25 & 0,2 & 287,4 & 0,15 & 0,63 \\
\hline $\mathbf{3}$ & 361,35 & 0,2 & 361,4 & 0,05 & 0,63 \\
\hline $\mathbf{4}$ & 536,65 & 0,2 & 536,5 & $-0,15$ & 0,61 \\
\hline $\mathbf{5}$ & 640,55 & 0,2 & 640,5 & $-0,05$ & 0,61 \\
\hline
\end{tabular}


Nilai Koreksi pada lamda 5 titik tabel di atas, semua koreksi masih masuk dalam toleransi $\pm 1 \mathrm{~nm}$ untuk area UV dan $2 \mathrm{~nm}$ utk area Visibel. Maka instrumen masih akurasi dalam penunjukan lamdanya dan nilai pergeserannya tidak bermakna.

Pengukuran Akurasi Panjang Gelombang dengan menggunakan Didymium diambil 5 titik panjang gelombang didapat hasil:

Tabel 5. Data pengukuran Akurasi Panjang Gelombang dengan menggunakan Didymium

\begin{tabular}{|c|c|c|c|c|c|c|c|c|c|c|}
\hline $\begin{array}{c}\text { Panjang } \\
\text { Gelombang dari } \\
\text { Standar NRC (nm) }\end{array}$ & $\mathbf{1}$ & $\mathbf{2}$ & $\mathbf{3}$ & $\mathbf{4}$ & $\mathbf{5}$ & $\mathbf{6}$ & $\mathbf{7}$ & $\mathbf{8}$ & $\mathbf{9}$ & $\mathbf{1 0}$ \\
\hline 329,45 & 329,5 & 329,5 & 329,5 & 329,5 & 329,5 & 329,5 & 329,5 & 329,5 & 329,5 & 329,5 \\
\hline 472,15 & 472,0 & 472,0 & 472,0 & 472,0 & 472,0 & 472,0 & 472,0 & 472,0 & 472,0 & 472,0 \\
\hline 512,40 & 512,5 & 512,5 & 512,5 & 512,5 & 512,5 & 512,5 & 512,5 & 512,5 & 512,5 & 512,5 \\
\hline 681,10 & 681,0 & 681,0 & 681,0 & 681,0 & 681,0 & 681,0 & 681,0 & 681,0 & 681,0 & 681,0 \\
\hline 875,50 & 875,5 & 875,5 & 875,5 & 875,5 & 875,5 & 875,5 & 875,5 & 875,5 & 875,5 & 875,5 \\
\hline
\end{tabular}

Tabel 6. Hasil pengukuran Akurasi Panjang Gelombang dengan menggunakan Didymium

\begin{tabular}{|c|c|c|c|c|c|}
\hline No & $\begin{array}{c}\text { Panjang } \\
\text { Gelombang } \\
\text { dari } \\
\text { Sertifikat } \\
\text { Hellma }\end{array}$ & $\begin{array}{c}\text { Ketidakpastian } \\
\text { Standar ( } \pm \text { nm }\end{array}$ & $\begin{array}{c}\text { Rata-rata } \\
\text { pembacaan } \\
\text { panjang } \\
\text { gelombang(nm) }\end{array}$ & Koreksi & $\begin{array}{c}\text { Ketidakpastian } \\
( \pm) \mathrm{nm}\end{array}$ \\
\hline 1 & 329,5 & 0,2 & 329,5 & 0,1 & 0,61 \\
\hline 2 & 472,2 & 0,2 & 472,0 & $-0,1$ & 0,61 \\
\hline 3 & 512,4 & 0,2 & 512,5 & 0,1 & 0,61 \\
\hline 4 & 681,1 & 0,2 & 681,0 & $-0,1$ & 0,61 \\
\hline 5 & 875,5 & 0,2 & 875,5 & 0,0 & 0,61 \\
\hline
\end{tabular}

Nilai Koreksi pada lamda 5 titik tabel di atas, semua koreksi masih masuk dalam toleransi $\pm 1 \mathrm{~nm}$ untuk area UV dan $2 \mathrm{~nm}$ utk area Visibel. Maka instrumen masih akurasi dalam penunjukan lamdanya dan nilai pergeserannya tidak bermakna. Pengukuran akurasi fotometri dengan larutan Kalium dikromat 0,006\% dan $0,06 \%$ dalam larutan $\mathrm{HClO}_{4} 0,001 \mathrm{~N}$, pada instrumen didapat hasil: 
Tabel 7. Data pengukuran akurasi fotometri dengan larutan Kalium dikromat $0,006 \%$ dan $0,06 \%$ dalam larutan $\mathrm{HClO}_{4} 0,001 \mathrm{~N}$

\begin{tabular}{|c|c|c|c|c|c|c|c|c|c|c|c|}
\hline Standar & $\begin{array}{c}\text { Panjang } \\
\text { Gelombang } \\
(\mathbf{n m})\end{array}$ & $\mathbf{1}$ & $\mathbf{2}$ & $\mathbf{3}$ & $\mathbf{4}$ & $\mathbf{5}$ & $\mathbf{6}$ & $\mathbf{7}$ & $\mathbf{8}$ & $\mathbf{9}$ & $\mathbf{1 0}$ \\
\hline $\begin{array}{c}\mathbf{0 , 0 0 6 \%} \\
\text { potassiu } \\
\mathbf{m}\end{array}$ & 235,0 & 0,748 & 0,748 & 0,748 & 0,748 & 0,748 & 0,748 & 0,748 & 0,747 & 0,747 & 0,747 \\
\cline { 2 - 11 } & 257,0 & 0,873 & 0,873 & 0,873 & 0,873 & 0,873 & 0,873 & 0,873 & 0,873 & 0,873 & 0,873 \\
\cline { 2 - 11 } $\begin{array}{c}\text { dikromat } \\
\text { dalam } \\
\text { asam } \\
\text { perklorat }\end{array}$ & 313,0 & 0,295 & 0,295 & 0,295 & 0,295 & 0,295 & 0,295 & 0,295 & 0,295 & 0,295 & 0,295 \\
\hline $\begin{array}{c}\mathbf{0 , 0 6 \%} \\
\text { pottasium } \\
\text { dikromat } \\
\text { solution }\end{array}$ & 430,0 & 0,653 & 0,653 & 0,653 & 0,652 & 0,652 & 0,653 & 0,652 & 0,653 & 0,653 & 0,652 \\
\hline
\end{tabular}

Tabel 8. Hasil pengukuran akurasi fotometri dengan larutan Kalium dikromat $0,006 \%$ dan $0,06 \%$ dalam larutan $\mathrm{HClO}_{4} 0,001 \mathrm{~N}$

\begin{tabular}{|c|c|c|c|c|}
\hline \multirow{2}{*}{ Standar } & $\begin{array}{c}\text { Panjang } \\
\text { Gelombang } \\
(\mathrm{nm})\end{array}$ & $\begin{array}{c}\text { Rata - Rata } \\
\text { Nilai Abs }\end{array}$ & Toleransi & Keterangan \\
\hline \multirow{2}{*}{$\begin{array}{c}\text { 0,006\% potassium } \\
\text { dikromat dalam asam } \\
\text { perklorat }\end{array}$} & 235,0 & 124,6 & 122,9 to 126,2 & Masuk Toleransi \\
\cline { 2 - 5 } & 313,0 & 49,2 & 47,0 to 50,3 & Masuk Toleransi \\
\cline { 2 - 5 } & 350,0 & 108,8 & 105,6 to 109,0 & Masuk Toleransi \\
\hline $\begin{array}{c}\text { 0,06\% pottasium } \\
\text { dikromat solution }\end{array}$ & 430,0 & 15,9 & 15,7 to 16,1 & Masuk Toleransi \\
\hline
\end{tabular}

Nilai absorbansi pada pembacaan akurasi fotometri setelah dimasukan dalam perhitungan nilai $E$ (spesifik absorbansi) masih masuk dalam toleransi keberterimaan sesuai dengan tabel, dimana nilai $\mathbf{E}_{1 \mathrm{~cm}}^{1 \%}$ pada daerah panjang gelombang tertentu harus terletak pada kisaran absorbansi tertentu.

Pengukuran sinar sesatan/straylight dengan menggunakan larutan $\mathrm{KCl} 1,2 \%$ pada lamda $198 \mathrm{~nm}$, didapat data hasil :

Tabel 9. Data Pengukuran/straylight dengan menggunakan larutan $\mathrm{KCl} 1,2 \%$ pada lamda $198 \mathrm{~nm}$

\begin{tabular}{|c|c|c|c|c|c|c|c|c|c|c|c|}
\hline Standar & $\begin{array}{c}\text { Panjang } \\
\text { gelombang } \\
\mathbf{( n m})\end{array}$ & $\mathbf{1}$ & $\mathbf{2}$ & $\mathbf{3}$ & $\mathbf{4}$ & $\mathbf{5}$ & $\mathbf{6}$ & $\mathbf{7}$ & $\mathbf{8}$ & $\mathbf{9}$ & $\mathbf{1 0}$ \\
\hline $\begin{array}{c}\mathbf{K C l} \\
\mathbf{1 , 2} \% \\
\mathbf{b} / \mathbf{v}\end{array}$ & 198,0 & 3,111 & 3,075 & 3,167 & 3,124 & 3,042 & 3,078 & 3,101 & 3,139 & 3,053 & 3,076 \\
\hline
\end{tabular}




\section{A. Irawan/Vol 1 (2) 2019, 1-9}

Tabel 10. Hasil Pengukuran/straylight dengan menggunakan larutan $\mathrm{KCl} 1,2 \%$ pada lamda $198 \mathrm{~nm}$

\begin{tabular}{|c|c|c|}
\hline $\begin{array}{c}\text { Panjang } \\
\text { Gelombang } \\
\text { (nm) }\end{array}$ & $\begin{array}{c}\text { Absorbansi } \\
\text { rata-rata }\end{array}$ & $\begin{array}{c}\text { Nilai } \\
\text { Abs } \\
\text { tanpa } \\
\text { cahaya } \\
\text { sesatan }\end{array}$ \\
\hline 198,0 & 3,097 & $>2$ \\
\hline
\end{tabular}

Pada pengukuran straylight dengan menggunakan larutan $\mathrm{KCl} 1,2 \%$ pada lamda $198 \mathrm{~nm}$ didapat nilai absorbansi $>2$, maka instrumen belum mengalami kebocoran sinar.

Pengukuran daya pisah/ resulotion dengan menggunakan larutan Toluen dalam Heksan 0,02\% pada instrumen, panjang gelombang 268,7 $\mathrm{nm}$ dan $267,0 \mathrm{~nm}$, didapat hasil:

Tabel 11. Data Pengukuran resulotion dengan menggunakan larutan Toluen dalam Heksan $0,02 \%$

\begin{tabular}{|c|c|c|c|c|c|c|c|c|c|c|c|}
\hline Standar & $\begin{array}{c}\text { Panjang } \\
\text { Gelombang } \\
(\mathbf{n m})\end{array}$ & $\mathbf{1}$ & $\mathbf{2}$ & $\mathbf{3}$ & $\mathbf{4}$ & $\mathbf{5}$ & $\mathbf{6}$ & $\mathbf{7}$ & $\mathbf{8}$ & $\mathbf{9}$ & $\mathbf{1 0}$ \\
\hline $\begin{array}{c}\text { Toluen } \\
\mathbf{0 . 0 2} \% \\
\mathbf{b} / \mathbf{v} \text { in } \\
\text { Heksan }\end{array}$ & 268,7 & 0,392 & 0,392 & 0,393 & 0,393 & 0,392 & 0,392 & $\begin{array}{c}0,39 \\
2\end{array}$ & 0,392 & 0,392 & 0,392 \\
\hline & 267,0 & 0,192 & 0,192 & 0,192 & 0,192 & 0,192 & 0,193 & $\begin{array}{c}0,19 \\
\mathbf{2}\end{array}$ & 0,192 & 0,192 & 0,192 \\
\hline
\end{tabular}

Tabel 12. Hasil Data Pengukuran resulotion dengan menggunakan larutan Toluen dalam Heksan $0,02 \%$

\begin{tabular}{|c|c|c|c|}
\hline Panjang Gelombang (nm) & $\begin{array}{c}\text { Absorbansi } \\
\text { rata-rata }\end{array}$ & $\begin{array}{c}\text { Ratio Abs } \\
\text { Pembacaan }\end{array}$ & $\begin{array}{c}\text { Toleransi } \\
\text { Ratio }\end{array}$ \\
\cline { 1 - 2 } 268,7 & 0,392 & \multirow{2}{*}{2,0416} & $>-1,5$ \\
\cline { 1 - 2 } 267,0 & 0,192 & & \\
\hline
\end{tabular}

Pengukuran daya pisah/resulotion dengan menggunakan larutan Toluen dalam Heksan 0,02\% pada instrument, panjang gelombang $268,7 \mathrm{~nm}$ dan 267,0 $\mathrm{nm}$ di peroleh nilai ratio absorbansi ke dua lamda masih diatas 1,5, maka kemampuan pemisahan alat masi masuk kreteria.

Hasil Pengukuran Linieritas Detektor dengan menggunakan larutan seri standar Phospat konsentrasi 0 ppm sampai dengan $32 \mathrm{ppm}$ pada panjang gelombang $430 \mathrm{~nm}$ adalah :

Tabel 13.Data pengukuran Linieritas Detektor

\begin{tabular}{|c|c|c|c|c|c|c|c|c|c|c|}
\hline \multirow{2}{*}{$\begin{array}{l}\text { Konsentrasi } \\
\text { Larutan Standar } \\
\text { Phospat (ppm) }\end{array}$} & \multicolumn{10}{|c|}{ Pembacaan Larutan Phospat pada Panjang Gelombang 430,0 nm } \\
\hline & 1 & 2 & 3 & 4 & 5 & 6 & 7 & 8 & 9 & 10 \\
\hline 0 & 0,000 & 0,000 & 0,000 & 0,000 & 0,000 & 0,000 & 0,000 & 0,000 & 0,000 & 0,000 \\
\hline 1 & 0,015 & 0,015 & 0,015 & 0,015 & 0,015 & 0,015 & 0,015 & 0,015 & 0,015 & 0,015 \\
\hline 2 & 0,030 & 0,030 & 0,030 & 0,030 & 0,030 & 0,030 & 0,030 & 0,030 & 0,030 & 0,030 \\
\hline 4 & 0,057 & 0,057 & 0,057 & 0,057 & 0,057 & 0,057 & 0,057 & 0,057 & 0,057 & 0,057 \\
\hline 8 & 0,113 & 0,113 & 0,113 & 0,113 & 0,113 & 0,113 & 0,113 & 0,113 & 0,113 & 0,113 \\
\hline 16 & 0,225 & 0,225 & 0,225 & 0,225 & 0,225 & 0,225 & 0,225 & 0,225 & 0,225 & 0,225 \\
\hline 32 & 0,448 & 0,448 & 0,448 & 0,448 & 0,448 & 0,448 & 0,448 & 0,448 & 0,448 & 0,448 \\
\hline
\end{tabular}




\section{A. Irawan/Vol 1 (2) 2019, 1-9}

$\begin{array}{ccc}\text { Pengukuran linieritas } & \text { detektor } \\ \text { dengan membaca standar Phospat }\end{array}$ dikorelasikan antara nilai konsentrasi masing-masing standar terhadap nilai

Tabel 14. Hasil pengukuran Linieritas Detektor

\begin{tabular}{|c|c|c|}
\hline \multirow{4}{*}{ Standar } & Konsentrasi & $\begin{array}{c}\text { Rata - Rata } \\
\text { Pembacaan } \\
\text { Absorbansi pada } \lambda \\
=430,0\end{array}$ \\
\hline \multirow{4}{*}{$\begin{array}{c}\text { Standar } \\
\text { Phospat }\end{array}$} & 0,00 & 0,000 \\
\cline { 2 - 3 } & 1,00 & 0,015 \\
\cline { 2 - 3 } & 2,00 & 0,030 \\
\cline { 2 - 3 } & 4,00 & 0,057 \\
\cline { 2 - 3 } & 8,00 & 0,113 \\
\cline { 2 - 3 } & 16,00 & 0,225 \\
\cline { 2 - 3 } & 32,00 & 0,448 \\
\hline
\end{tabular}

\section{B. PEMBAHASAN}

Pada kegiatan kalibrasi Spektrofotometer ini diperoleh beberapa data hasil pengukuran, yaitu :

Baseline Flatness rentang ukur $1100 \mathrm{~nm}$ - $190 \mathrm{~nm}$ nilai Absorbansi 0,0002 Abs toleransi $\pm 0,0010 \mathrm{Abs}$, maka Instrumen masih memiliki baseline yang rendah dan belum melampaui nilai toleransi. Baseline Stability diukur pada lamda 700 $\mathrm{nm}$ selama 1 jam memperoleh data niali absorbansi $0,0003 \mathrm{Abs} / \mathrm{H}$, sedang Toleransi $0,0010 \mathrm{Abs} / \mathrm{H}$ atau kurang, maka instrumen masih memiliki baseline yang stabil. Pada Pengkuran Akurasi Panjang Gelombang dengan menggunakan filter Holmium Oxide glass di ambil 5 titik lamda dengan pembacaan $10 \times$ perulangan. Hasil yang didapat semua koreksi masih masuk dalam toleransi $\pm 1 \mathrm{~nm}$ untuk area UV dan $2 \mathrm{~nm}$ utk area Visibel. Maka instrumen masih akurasi dalam penunjukan lamdanya dan nilai pergeserannya tidak bermakna. Begitu juga untuk pengukuran akurasi panjang gelombang menggunakan filter Holmium rata-rata absorbansinya diperoleh nilai $\mathrm{R}=1$ maka kemampuan detektor untuk membaca masih linier.

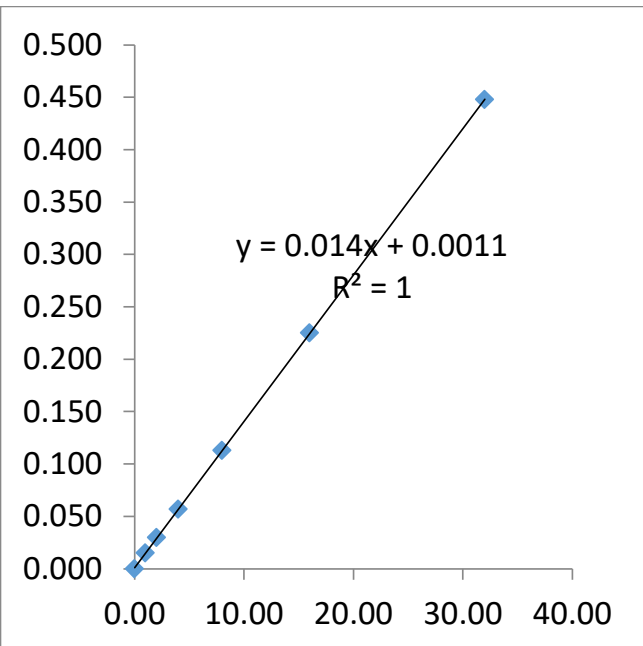

Oxide Liquid. Pada Pengkuran Akurasi Panjang Gelombang dengan menggunakan filter Didymium, nilai Koreksi pada lamda 5 titik tabel di atas, semua koreksi masih masuk dalam toleransi $\pm 1 \mathrm{~nm}$ untuk area UV dan $2 \mathrm{~nm}$ utk area Visibel. Maka instrumen masih akurasi dalam penunjukan lamdanya dan nilai pergeserannya tidak bermakna. Pengukuran akurasi fotometri dengan larutan Kalium dikromat $0,006 \%$ dan $0,06 \%$ dalam larutan $\mathrm{HClO}_{4} \quad 0,001 \mathrm{~N}$, pada instrumen didapat hasil: Nilai absorbansi pada pembacaan akurasi fotometri setelah dimasukan dalam perhitungan nilai $\mathrm{E}$ (spesifik absorbansi) masih masuk dalam toleransi keberterimaan sesuai dengan tabel, dimana nilai $\mathbf{E}_{1 \mathrm{~cm}}^{1 \%}$ pada daerah panjang gelombang tertentu harus terletak pada kisaran absorbansi tertentu.

Pada pengukuran straylight dengan menggunakan larutan $\mathrm{KCl} 1,2 \%$ pada lamda $198 \mathrm{~nm}$ dengan perulangan $10 \mathrm{x}$ di dapat nilai absorbansi $>2$, maka 
instrument belum mengalami kebocoran sinar. Pengukuran daya pisah/resulotion dengan menggunakan larutan Toluen dalam Heksan $0,02 \%$ pada instrumen, panjang gelombang $268,7 \mathrm{~nm}$ dan 267,0 $\mathrm{nm}$ diperoleh nilai ratio absorbansi kedua lamda masih di atas 1,5, maka kemampuan pemisahan alat masih masuk kreteria. Hasil Pengukuran Linieritas Detektor dengan menggunakan larutan seri standar Phospat konsentrasi $0 \mathrm{ppm}$ sampai dengan $32 \mathrm{ppm}$ pada panjang gelombang $430 \mathrm{~nm}$ adalah di korelasikan antara nilai konsentrasi masing-masing standar terhadap nilai rata-rata absorbansinya diperoleh nilai $\mathrm{R}=1$ maka kemampuan detektor untuk membaca masih linier.

\section{KESIMPULAN}

Berdasarkan data perolehan kegiatan kalibrasi Spektrofotometer UVVIS (Shimadzu UV-1800) dapat disimpulkan :

1. Dari setiap data parameter kalibrasi yang diperoleh, semua masih dalam batas toleransi yang di perbolehkan sesuai dengan nilai standar, tidak ada yang di luar batas toleransi .

2. Instrumen Spektrophotometer UVVIS (Shimadzu UV-1800) di LPPT UGM ujuk kinerja dan performa masih bagus, sehingga data dari hasi pembacaannya valid dan bisa menunjang kegiatan penelitian dan pengujian

\section{SARAN}

Kegiatan kalibrasi Spektrofotometer dapat dilaksanankan dengan rutin dalam periode tertentu.

Kalibrasi Spektrofotometer diharapkan dapat dilaksanakan di laboratorium di lingkungan UGM kususnya dan di luar pada umumnya.

\section{DAFTAR PUSTAKA}

Cerffied UV/VIS Reference Materials Guidelines - Hellma Analytics

IKK/5.5/UV-02 - Instruksi Kerja Kalibrasi Spektrofotometri UV-1700 Pharmaspec

IKO/5.5/UV-03 - Instruksi Kerja Operasional Spektrofotometer Shimadzu UV-1800

ISO Guide 99:1993. International vocabulary of basic and general terms in metrology (VIM)

Pengecekan Kalibrasi Antara dan Verifikasi Peralatan Dalam Laboratorium Pengujian Sesuai Dengan SNI ISO/IEC 17025;2008 